
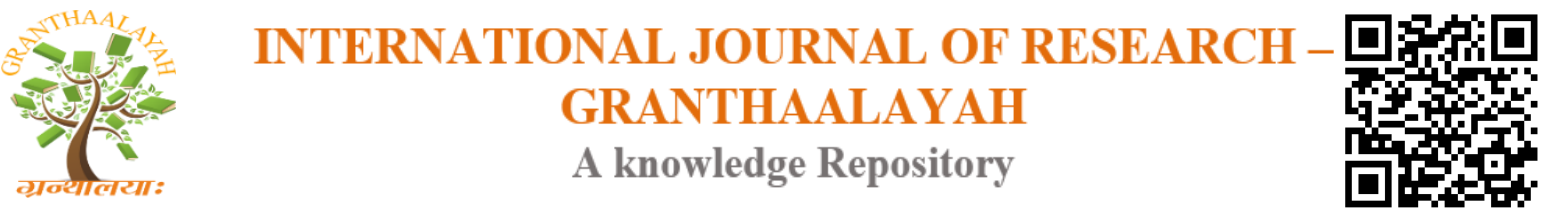

Social

\title{
ATTITUDE OF SENIOR SECONDARY SCHOOL STUDENTS TOWARDS AGRICULTURAL SCIENCES AND TRAININGS IN OGBOMOSO NORTH LOCAL GOVERNMENT AREA OF OYO STATE
}

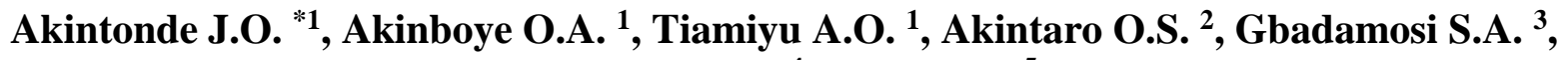 \\ Bamidele B.S. ${ }^{4}$, Alabi A.A. 5 \\ ${ }^{1}$ Department of Agricultural Extension and Rural Development, Ladoke Akintola University of \\ Technology, P.M.B. 4000, Ogbomoso, Oyo State, Nigeria. \\ ${ }^{2}$ Teaching and Research Farm, Ladoke Akintola University of Technology, \\ Ogbomoso, Oyo State, Nigeria. \\ ${ }^{3}$ Department of Agricultural Education, Osun State College of Education, P.M.B. 207, Ila- \\ Orangun, Nigeria. \\ ${ }^{4}$ Department of Agricultural Extension and Management, Federal College of Agriculture, \\ P.M.B. 5029, Moore Plantation, Ibadan, Oyo State
}

\begin{abstract}
The study assesses the attitude of senior secondary school students towards agriculture as a profession in some selected secondary schools in Ogbomoso North Local Government Area of Oyo State. One hundred respondents were randomly selected from five senior secondary schools purposively selected due to their questionnaire. The data obtained were analyzed with the aid of frequency count, percentages and cumulative percentage while correlation analysis was used to test the hypothesis. The findings reveal the personal characteristic of the respondents sampled as well as their level of interest in agriculture as a profession. The statistical analysis performed on the respondents' attitude towards agriculture as a profession revealed that there was significant relationship to the respondents' gender, educational level father and mother's occupation respectively while age and religion were statistically insignificant.
\end{abstract}

Keywords: Attitude; Senior Secondary School; Agricultural Science; Training.

Cite This Article: Akintonde J.O., Akinboye O.A., Tiamiyu A.O., Akintaro O.S., Gbadamosi S.A., Bamidele B.S., and Alabi A.A.. (2019). "ATTITUDE OF SENIOR SECONDARY SCHOOL STUDENTS TOWARDS AGRICULTURAL SCIENCES AND TRAININGS IN OGBOMOSO NORTH LOCAL GOVERNMENT AREA OF OYO STATE." International Journal of Research - Granthaalayah, 7(3), 130-135. 10.29121/granthaalayah.v7.i3.2019.952.

\section{Introduction}

In the early stages of economic development, agriculture plays a dominant role is the employment of resource and I the generation of income. This was the case prior to oil $600 \mathrm{~m}$ era when agriculture 
employed more than $2 / 3$ of the labour force and contribute about $1 / 3$ of grass domestic products (Akpokadge, 1991). Agriculture is the base through which most developed nations achieved their industrialization. Bidmus (1996) opined that there is the need for Nigeria as a country to harness al agricultural inputs in such a manner to improve farm management practices so that adequate food would be produced for the teeming population of the county.

Nigeria is predominantly an agrarian nation, to buttress the, Aribisala (2003) posited that over $75 \%$ of the country's population depends directly or indirectly on agriculture for their livelihood. However, despite the enormous importance agriculture how in the life of the population in the country, it's activities are still dominated by the aged and illiterates in the rural areas, thus it is now very importance for youths to be involved in agriculture squarely so as to meet the increasing food demand of the population.

Ciroma (1994) opined that Nigerian youths are dynamic, energetic talented, aggressive, mobile and very out spoken though in our society, most youths are facing the problem of unemployment and if they can venture into agriculture with their present ability, and they will boost food production and at the same time reduce unemployment. Moreover, youths can easily adapt to modernized farming system where technology and new innovation will be practiced which may be difficult for the old hands to comprehend.

Naturally, as adults become aged, youths step in and in view this, Styart (1992) posited that agriculture should be make more attractive to the youths for them to embrace it and if the youths are ready to exploit the agricultural resources at their disposal, they would not only be gainfully employed but the society would be devoid of most social rice bedeviling the nation of present (Badmus, 199). The children who are brought up $\mathrm{n}$ the farming communities / rural areas are more susceptible to changes in behaviour as it relates to their environment and farming occupation. This is because in most cases, their parents are farmers and they too have been exposed to some aspect of farming hence there could be change in the children attitude toward agriculture as a career (Okunlola, 1998).

The concept "career" has been defined in different ways by various authors and none of these definitions in best or universal they all agreed to the fact that the term denotes the profession of an individual in a field of work through the employable years of his life. Career can also be viewed as a developmental process an individual passes through from childhood to adulthood in which he involves himself in educational and vocational training which will further satisfy his/her occupational needs (Carew,1997). Ekpere (1995) in his own view believes that a career in the occupation in which an individual finally finds himself in the horse of trying to earn a living. Furthermore, career to him, is not contingents upon the occupational aspiration of an individual, be contended that there will be a significant differences between the occupations young people aspire to and which they actually achieve overtime. This he said was attributed to some factors such as time, social status, parental education and the students' perception of the real word-work.

Apparently, in an effort to stimulate the youths interest toward taking agriculture as a career in the country, agricultural science and farming were made compulsory in most primary and secondary schools; despite all these efforts, there is still negative attitude on the path of the youths towards agriculture as a profession. Similarly, youths' interest in agriculture has been downplayed due to 
some factors such as low farm income, societal views of the practice and value of agriculture so also in the government attitude towards improving agricultural production which has discourages the younger generations from going into farming. (Newwatch, 1995).

In view of this, the study intends to assess the attitude of senior secondary school students towards developing a career in agriculture. Specifically, the study intends to identify the personal characteristics of the respondents, and determine their level of interest towards agriculture as a profession. It was hypothesized that there was no significant relationship between respondents' personal characteristics and their attitude towards agriculture as a profession.

\section{Methodology}

The study was conducted in Ogbomoso North Local Government Area of Oyo State. The Local Government Area consist of 31 secondary schools, In the study area, five (5) secondary schools were purposively selected due to their agrarian background; in each of the selected schools, 20 respondents were randomly sampled from senior secondary 2 and 3 respectively i.e. ten students were sampled in each schools. The population of the study consists of all students in senior secondary school 2 and 3 respectively including both male and female.

The lists of students in senior secondary 2 and 3 respectively was used in the selection and in all 100 students constitute the sample size. Both descriptive and inferential statistics were used to analyze the data. Descriptive statistics used include frequency count percentages and cumulative percentages while inferential statistic used to test for relationship between the varieties (hypotheses) was person's product moment correlation (PPMC).

\section{Results and Discussions}

\subsection{Personal Characteristics of Respondents}

Data presented on table 1 reveals that majority of the sampled respondents $(63 \%)$ were male while remaining $37 \%$ accounted for female respondents. The implication of the result is that there more male respondents in school than the female respondents which may be as a result of the fact that few people believe in educating the girl child compare to the male child. Similarly, it can be observed on the table that the majority of the respondents $(75 \%)$ were within the age group of 15 - 19 years while $20 \%$ of the respondents were within the age group of 20years and above and only $5 \%$ were below $15 y e a r s$ of age. This indicates that the respondents were still very young and active and the right attitude towards agriculture as a career can be imbued into them. The table further reveals that $64 \%$ of the respondents practice Christianity as religion while the remaining $36 \%$ accounted for Muslim respondents.

Further perusal of the finding on the table shows that majority of the sampled respondents' fathers $(36 \%)$ engaged in agriculture as their primary occupation while $26 \%$ engaged in trading and $28 \%$ were civil servant. The remaining $10 \%$ engaged in other types of primary occupation. Also, $18 \%$ of the respondents' mothers were farmers by profession while $61 \%$ were traders and $16 \%$ were civil servants. Only 5\% engaged in other types of primary occupation. The implication of this result is that irrespective of the respondents parents primary occupation the right attitude can be 
put into these students by their parents if really they understand the importance of agriculture to the country economy and to upliftment of their living standard because agriculture of no longer carried out with crude implements but heavy machineries thus longer scale farming can be encouraged.

\subsection{Respondents Level of Interest in Agriculture as A Profession}

Data presented on table 2 shows that majority of the respondents sampled (55\%) indicated that they have high interest in agriculture as a profession while $35 \%$ indicated moderate interest and $10 \%$ indicated low interest in agriculture as a career.

\subsection{Testing of Hypothesis}

Table 3 shows that there was significant relationship between respondents level of education, gender, father's occupation and mother's occupation while age and religion were insignificantly related to the attitude of the respondents' towards agriculture as a career. This implies that educational level, gender father's occupation and mother's occupation have positive influence on the respondents' choice of future career.

\section{Conclusions}

This study assess the attitude of senior secondary school towards agriculture as a career on some selected secondary schools in Ogbomoso North Local Government Area of Oyo State with particular focus on five secondary schools with agrarian background. The following conclusions were made based on the findings of the study.

1) Majority of the sampled respondents (63\%) were male, young and active (75\%) within the age group of $15-19$ years and practice Christianity (64\%).

2) About $36 \%$ of the respondents' father engaged in agriculture as their primary occupation, $18 \%$ accounted for mothers' who primary occupation was agriculture.

3) A larger proportion (55\%) showed high interest in taking up agriculture as a career.

4) There was significant relationship between respondents education, gender, father's and mother's primary occupation while age and religion were insignificantly related to their attitude toward agriculture as a profession.

\section{Recommendations}

Based on the findings of the study, the following recommendations were made:

1) Agriculture clubs and young farmers' club should be organized in schools where they are present bit not functional should be revived since His clubs/organization will expose the students to the importance of agricultural through new innovations and the technicalknowledge through agricultural shows seminars and workshops.

2) For further interest, the state government should mandate the principals of such schools to intensify efforts on practical agriculture on His will assist the students to have adequate practical experience.

3) Also, state ministry of agriculture should resuscitate farm settlement schemes for secondary school leavers where further practical experience can be obtained. 


\section{Appendix}

Table 1: Personal characteristics of the respondents

\begin{tabular}{|lcc|}
\hline Characteristics & Frequency & Percentage \\
\hline Sex & 63 & \\
Male & 37 & 63.0 \\
Female & & 37.0 \\
Age (Years) & 05 & \\
Below 15 & 75 & 5.0 \\
15 - 19 & 20 & 75.0 \\
20 and above & & 20.0 \\
Religion & 64 & \\
Christianity & 36 & 64.0 \\
Muslim & & 36.0 \\
Father' primary occupation & 36 & \\
Farming & 28 & 36.0 \\
Civil servant & 26 & 28.0 \\
Trading & 10 & 26.0 \\
Others & & 10.0 \\
Mothers' primary occupation & 18 & \\
Farming & 16 & 18.0 \\
Trading & 61 & 16.0 \\
Civil servant & 05 & 61.0 \\
Others & $\mathbf{1 0 0}$ & 5.0 \\
\hline Total & & $\mathbf{1 0 0 . 0}$ \\
\hline : Field Survey, & &
\end{tabular}

Source: Field Survey, 2010.

Table 2: Respondents level of interest on agriculture as a profession

\begin{tabular}{|lcc|}
\hline Interest level & Frequency & Percentage \\
\hline High & 55 & 55.0 \\
Moderate & 35 & 35.0 \\
Low & 10 & 10.0 \\
\hline Total & $\mathbf{1 0 0}$ & $\mathbf{1 0 0 . 0}$ \\
\hline
\end{tabular}

Source: Field Survey, 2010.

Table 3: Summary of the correlation analysis of the relationship between personal characteristics of the respondents and their attitude towards agriculture as a profession

\begin{tabular}{|lccc|}
\hline Personal characteristics & Correlation value & Sig. level & Remark \\
\hline Age & -0.304 & 0.250 & $\mathrm{NS}$ \\
Education & 0.901 & 0.001 & $\mathrm{~S}$ \\
Gender & 0.725 & 0.001 & $\mathrm{~S}$ \\
Religion & 0.220 & 0.400 & $\mathrm{NS}$ \\
Father's occupation & 0.748 & 0.001 & $\mathrm{~S}$ \\
Mothers' occupation & 0.646 & 0.001 & $\mathrm{~S}$ \\
\hline
\end{tabular}

At $5 \%$ level of significance 


\section{References}

[1] Akpokodge, O.O. (1991): Nigeria's Food import; implication for food security" Proceeding the National Conference Ibadan Socioeconomic group. University of Ibadan. Pg 27.

[2] Aribisala, E.A. (2003): Food Import Demand; Model for the Nigeria Economy". Proceeding of the National Conference or Management Problems of Agricultural Development Programmes in Nigeria. O.A.U Ile - ife.

[3] Badmus, K. (1996): “Agriculture and the Nigeria Youths". The Guardian Newspaper, Thursday may 23; pg 3.

[4] Carew, P.F. (1997): "Some Consideration for the Establishment of career Guidance in School". Nigeria Journal of Councelling and Development. Vol 2, pp 16-17.

[5] Ciroma, A. (1994): "Opening Address of the Honourable Minister of Agricultural. 19 ${ }^{\text {th }}$ National Convention of the Nigeria Association of Agricultural Students (NAAS), Ogun State University, Ago - Iwoye. Pg 2.

[6] Ekpere, J.A. (1995): Occupation Aspiration of Students in Agriculture" Journal of Education Research. Vol 2, No 2. Pp $79-80$.

[7] News Watch Magazine (1995): “The Nation's Food Crisis. Vol., No2 pp 20 - 21.

[8] Okunlola, J.O. (1998): "The Attitude of Children Towards Agriculture as a profession in Nigeria a case Study of Ondo State. A paper Presented at Ogun State University, Ago - Iwoye, pg 2.

[9] Stuart, W.W. (1992): The Stages of Economic Growth. Cambridge University Press, London. Pg 185.

*Corresponding author.

E-mail address: joakintonde@ lautech.edu.ng 